\title{
Development of the crop coefficient for capsicum (Capsicum annum L.) under protected structures
}

\author{
CHITRA SHUKLA, S. R. BHAKAR and S.S. LAKHAWAT \\ Department of Soil and Water Engineering, CTAE, MPUAT, Udaipur, 313001, Rajasthan \\ email: chitra.shukla0@gmail.com
}

\begin{abstract}
The study was undertaken to determine the crop water requirement and crop coefficient for capsicum (Capsicum annum L.) at plasticulture farm of CTAE, Udaipur, Rajasthan under four small protected structures; (i) shednet house (ii) insectnet house (iii) poly house with ventilation through shed net and (iv) polyhouse with ventilation through insect net. The reference evapotranspiration under each structure was determined by Penman Monteith method based on microclimatic observations under all four protected structures. Crop evapotranspiration was determined by soil moisture balance method. Reference evapotranspiration and crop coefficient observed minimum under structure covered with shadenet for all the growth stages. Reference evapotranspiration for shadenet house was $21.5 \%$ less than the reference evapotranspiration outside the structure. It was found that shadenet house minimized crop evapotranspiration by $33.4 \%$ as compared to outside crop evapotranspiration. However, the higher fruit yield per plant $\left(1720 \mathrm{~g} \mathrm{plant}^{-1}\right)$ was recorded under polyhouse with ventilation through insectnet, which was significantly superior over the all growing structures while the lowest yield (1285 g plant $\left.{ }^{-1}\right)$ was recorded under shadenet house.
\end{abstract}

Keywords: Reference evapotranspiration, crop evapotranspiration, protected structures, crop coefficient.

With the growing population land holding is reducing and need of vegetables are increasing. To overcome this problem protected cultivation is scientific invention through which protected cultivation can be multiplied many times per unit land and per unit water. Capsicum cv. 'Indira' botanically known as Capsicum annum placed in Solanceae family and classified as fruit vegetable crop. It is 6-10 months' crop. With the development of facility protected cultivation, more and more capsicum is grown in greenhouse to pursue the maximum economic profits. However, its cultivation is confined to warm and semi-arid countries where water is often a limiting factor for production (Dorjia etal., 2005).

According to Iwena (2002), hot pepper requires 1000 to $1500 \mathrm{~mm}$ of water during the growing season. According to FAO (1999) however, when the crop is grown extensively under rain fed conditions, high yields are obtained with rainfall of $600 \mathrm{~mm}$ to $900 \mathrm{~mm}$, well distributed over the growing season. Huguez and Philippe (1998) also indicated that the total water requirements were $750 \mathrm{~mm}$ to $900 \mathrm{~mm}$ and even up to $1250 \mathrm{~mm}$ for long growing periods and several pickings. Agodzo et al. (2003) indicated that the crop water requirements ranged between $300 \mathrm{~mm}-700 \mathrm{~mm}$ depending on the climatic condition and the season of the crop and the location.

The crop coefficient (Kc) values represent crop specific water use and is required for accurate estimation of irrigation requirement of different crop grown under different climatic conditions (Doorenbos and Pruitt 1977). Therefore, the present study has been undertaken to determine the crop coefficient of capsicum crop under each structure using crop water determined through sol moisture depletion method and reference evapotranspirataion determined with the help of Penmen Monteith method using climatic data of each structure.

\section{MATERIALS AND METHOD}

The experiment was carried out to study at plasticulture farm CTAE Udaipur. In this study the capsicum has been grown under four small size of $16 \times 4 \mathrm{~m}$ each, naturally ventilated protected structures i.e. shednet house, insectnet house, poly house with shade net vents, poly house with insectnet vents, during February to July, 2013. The plant spacing was followed as $50 \times 30 \mathrm{~cm}$. Each structure comprised of 400 plants of capsicum in four beds of 100 each. Irrigation was given through gravity fed drip irrigation system of 4 laterals in each structure. The crop was taken during 29 January 2013 to 15 July 2013. 
Table.1: Growth stages, ET0 $\left(\mathrm{mm} \mathrm{day}^{-1}\right), \mathrm{Kc}$ and ETc $\left(\mathrm{mm} \mathrm{day}^{-1}\right)$ for all the growth stages.

\begin{tabular}{lllll}
\hline Structures & Parameters & \multicolumn{3}{c}{ Growth Stages } \\
\cline { 3 - 5 } Structure-1 & & Initial & Mid & Late \\
& ETc & 1.8 & 8.78 & 2.05 \\
Structure-2 & ET0 & 3.75 & 7.99 & 3.81 \\
& Kc & 0.48 & 1.01 & 0.54 \\
ETc & 2.1 & 9.62 & 3.04 \\
Structure-3 & ET0 & 3.83 & 8.83 & 4.23 \\
& Kc & 0.55 & 1.09 & 0.72 \\
Structure-4 & ETc & 1.87 & 9.22 & 2.96 \\
& ET0 & 3.91 & 9.04 & 4.42 \\
Kc & 0.48 & 1.02 & 0.67 \\
Outside & ETc & 1.99 & 8.1 & 3.04 \\
& ET0 & 3.77 & 8.62 & 4.61 \\
& Kc & 0.53 & 0.94 & 0.66 \\
& ETc & 2.59 & 7.68 & 9.52 \\
& ET0 & 4.31 & 6.68 & 10.58 \\
\hline
\end{tabular}

Table 2: Effect of different types of growing structures on quantity parameter of Capsicum cv. 'Indira'

\begin{tabular}{llllllll}
\hline Structures & Structure 1 & Structure 2 & Structure 3 & Structure 4 & SE m \pm & CD $(\mathrm{P}=0.05)$ & $\mathrm{CV}(\%)$ \\
\hline Fruit yield/ plant $(\mathrm{g})$ & 1285 & 1440 & 1535 & 1720 & 51.06 & 163.36 & 6.83 \\
Fruit yield $\left(\mathrm{t} \mathrm{ha}^{-1}\right)$ & 51.4 & 57.6 & 61.4 & 68.8 & 2.25 & 7.20 & 7.53 \\
\hline
\end{tabular}

\section{Micro climate observation inside each structure}

Four thermometers were installed at 1 meter above the ground level to monitor the wet bulb temperature, dry bulb temperature, maximum temperature and minimum temperature in all four structures. Pyranometer was used to record the daily solar radiation in all four structures. Wind speed could not be monitored as effect of the wind was minimal hence it was considered negligible in all four structures. Wet bulb, dry bulb temperature and solar radiation were used to calculate relative humidity and light intensity in all four structures.

\section{Protected structures}

The covering material is used in such a way that inside structure covered with shade net: maximum shading has been provided, inside structure covered with insect net: minimum shading has been provided and inside structure covered with $200 \mu$ LDPE polythene and natural ventilation through shade net as well as inside structure covered with $200 \mu$ LDPE polythene and natural ventilation through insect net natural ventilation window has been provided using shade net and insect net to provide minimum and maximum ventilation respectively.

Four types of raised arch shaped structures were used for study-

Structure - 1: Shed net house (structure covered with shade net only)

Structure - 2: Insect net house (structure covered with insect net only)

Structure - 3: Poly house with shed net ventilation (structure covered with $200 \mu \mathrm{LDPE}$ polythene and natural ventilation through shade net: Top of the structure covered by polythene sheet, side opening and top vents covered by shade net with provision of $1.0 \mathrm{~m}$ wide apron from the ground.)

Structure - 4: Poly house with insect net ventilation (structure covered with $200 \mu$ LDPE polythene and natural ventilation through insect net: Top of the structure covered by polythene sheet, side opening $(16 \mathrm{~m} \times 1.7 \mathrm{~m})$ and top vents covered by insect net with provision of $1.0 \mathrm{~m}$ wide 
apron from the ground.

\section{Determination of ETo, ETc and Kc}

The crop water requirement (ETc) is defined as the depth (or amount) of water needed to meet the water loss through evapotranspiration. ETc and ETo inside each structure was calculated by gravimetric method and PenmanMonteith equation (Allen et al., 1998) respectively. This was calculated for the initial, mid-season and the late season growth stages for the various treatments.

$$
\mathrm{ETc}=\mathrm{ETo} \times \mathrm{Kc}
$$

or,

$$
\mathrm{Kc}=\mathrm{ETc} / \mathrm{ETo}
$$

For row crop like capsicum the measurement was made near the plant. Care was taken that root zone of plant should not be disturbed. The sampling was done at $7.5,15$, 30 and $45 \mathrm{~cm}$ depth from where the plants extracts maximum amount of water.

\section{RESULTS AND DISCUSSION}

The results obtained from this study revealed that reference evaporation for outside was $1343.3 \mathrm{~mm}$. It was found that the crop evapotranspiration was $1391.5 \mathrm{~mm}$ for outside condition. After determining the reference evapotranspiration and crop evapotranspiration, the crop coefficient was developed for initial, mid-season and late stages of capsicum crop under four protected structures with different cladding material. Crop coefficient was estimated minimum but equal (0.48) under Structure-1 and Structure- 3 and maximum (0.55) under Struture- 2 for initial stage. However, Kc for mid-season stage was estimated minimum under Structure-4 (0.94) and maximum under Structure-2 (1.09) and it was estimated minimum under Structure-1 (0.54) and maximum under Structure-2 (0.72) for late season stage. Crop coefficient for capsicum in open condition suggested by FAO 56 is $0.6,1.15$ and 0.9 for initial, mid and late season respectively was taken for comparison purpose. It was found that under all protected structures for all growth stages estimated crop coefficient values were lesser than the values suggested by FAO-56.

ET0, Kc and ETc for all the growth stages are indicated in Table 1. These values are quite well with those obtained by Iwena (2002).

However, the higher fruit yield per plant (1720 g plant $^{-1}$ ) and highest crop evapotranspiration was recorded under Structure-4, which was significantly superior over the all protected structures while the lowest yield (1285 g plant $^{-1}$ ) and lowest crop evapotranspiration was recorded under Structure-1.

\section{CONCLUSION}

It was found that the minimum reference evaporation is found under Structure - 1 and maximum has been recorded under Structure-4. The maximum crop evapotranspiration was recorded under Structure-4 and minimum under Structure-1. On the basis of yield obtained and water saved inside each structure, Structure-4 was found most suited structure for capsicum crop in semi-arid region.

\section{REFERENCES}

Agodzo S.K., F.P. Huibers, F. Chenini, J.B. Van Lier and A. Duran, (2003). Use of wastewater in irrigated agriculture. Country studies from Bolivia, Ghana and Tunisia. Vol. 2: Ghana. Wageningen: WUR:p. 36.

Allen, R. K., L. S. Pereira, D. Raes and M. Smith. (1998). Crop evapotranspiration. Guideline for computing crop water requirements. FAO Irrigation and Drainage Paper No. 56. United Nations Food andAgricultural Organization, Rome.

Dorjia, K., M.H. Behboudiana and J.A. Zegbe-Dominguezb, (2005). Water relations, growth, yield, and fruit quality of hot pepper under deficit irrigation and partial rootzone drying. Sci. Hort. 104, 137-149.

Doorenbos, J. and W.O., Pruitt, (1977). Guidelines for predicting crop water requirements. Irrig. and Drain. Paper No. 24,2nd ed., Food Agric. Org., United Nations, Rome. FAO. Agriculture, food and water, Rome, Italy.

Grimes D.W. and L.E. Williams. (1990). Irrigation effects on plant. Water relations and Seedless grapevines. Crop Sci.30:255-260.

Huguez D. and Philippe De Leenor. (1998). Ways of Water; Runoff, Irrigation and Drainage. 4th Ed. Imperimie Guyot Braine-le-Chateau, Belgium.

Iwena O.A. (2002). Essential Agricultural Science for Senior Secondary Schools. Tonad Publishers Ltd., Ikeja. pp. 55-63.

Muthukrishnan C. R., T. Thangaraj and R. Chatterjee, (1986). Chilli and capsicum. In; Vegetable Crops in India. pp. 343. 